The Effects of Addition of Polysaccharide on Characteristics of Low Sugar - Nurbaya, et al Jurnal Pangan dan Agroindustri Vol. 9 No.2: 83-88, April 2021

Accepted: 13/07/2020, Reviewed: 04/09/2020, Published: 30/04/2021

\title{
THE EFFECT OF ADDITION OF POLYSACCHARIDE ON CHARACTERISTICS OF LOW SUGAR CUCUMBER SORBET
}

\author{
Syarifa Ramadhani Nurbaya*, Lukman Hudi, Intan Rohma Nurmalasari, \\ Awanda Rizky Amalia
}

Study Program of Agricultural Product Technology, Faculty of Science and Technology Universitas Muhammadiyah Sidoarjo

JI. Mojopahit 666B Sidoarjo

*Correspondence Authors, Email: syarifa@umsida.ac.id

\begin{abstract}
The purpose of this study is to determine the effect of adding various types of polysaccharides (CMC, xanthan gum, pectin, agar) and the percentage of polysaccharides $(0.5 \%$ and $1 \%)$ on the characteristics of cucumber sorbet with a low proportion of sugar. This study uses a Randomized Block Design (RBD) with eight treatments and three replications. The results show that the interaction between the types of polysaccharides and the percentage of polysaccharides significantly affects the value of brightness $(L)$ and yellowness $(b+)$ of the sorbet. Based on the results of this study, the best treatment for cucumber sorbet is the cucumber sorbet using $1 \%$ xanthan gum. Cucumber sorbet using polysaccharides and a low proportion of sugar can be made as a type of frozen snack that is beneficial to the human body.

Keywords: Cucumber sorbet, Percentage of polysaccharides, Polysaccharide type
\end{abstract}

\section{INTRODUCTION}

Cucumber (Curcumis sativus) is a food ingredient that contains dietary fiber and vitamins. Besides, cucumber also contains secondary metabolites, namely phytochemistry compounds. Phytochemistry compounds found in cucumbers, such as alkaloids and flavonoid, can function as antioxidants (Uzuazokaro, Okwesili, and Chioma, 2018). Antioxidant compounds can prevent oxidation reactions that can cause the formation of free radicals in the body (Salehi et al., 2018). So far, cucumber is used as a complement to fresh vegetables and is generally processed into various types of food products, such as salads, pickles, and ice. Cucumber can also be processed into sorbets.

Sorbet is a frozen snack made from a mixture of water, sugar, and fruit. The minimum fruit content in the sorbet is $25 \%$ (Hipólito et al., 2015). Unlike ice cream, sorbet does not involve the use of foods that contain fat (milk or cream) in the manufacturing process. Therefore, sorbet is a low-fat product. Even without the addition of fat, the sorbet can still have a "creamy" texture due to the combination of fruit components and sugar water ("simple syrup"). On the other hand, sugar (sucrose) has a high glycemic index (GI) value. A high glycemic index value means that consuming sugar can cause high blood sugar levels. This condition can harm the health of the body and cause degenerative diseases, such as diabetes mellitus.

Low-sugar sorbet can be made by reducing the sugar composition in its manufacture. However, in the sorbet product, the low sugar composition causes a large ice crystal sorbet. This causes the sorbet's texture to become hard. To overcome this, other ingredients are needed that can make the texture of the sorbet softer. Polysaccharides, which are hydrocolloids, can soften the texture of the sorbet. Hendrianto and Rukmi (2015) used CMC and arabic gum as a stabilizer in making tempe juice ice cream. Xanthan gum and pectin can soften sorbet as well. Besides, polysaccharides also have a lower glycemic index value than 
sugar, making them safer for health. This study aims to make low sugar cucumber sorbet by utilizing CMC, xanthan gum, agar, and pectin to improve the characteristics of sorbet which include overrun, melting rate, and total dissolved sorbet solid (Cahyadi and Widiantara, 2018; Ida et al., 2018).

\section{METHODOLOGY}

\section{Materials}

The materials used in this study was cucumber (Curcumis sativus) which was obtained from Larangan Market, Sidoarjo. Other ingredients such as CMC, agar, and sugar were obtained from the Cake Ingredient Shop, Sidoarjo. Raw pectin xanthan gum was obtained from a market in Surabaya.

\section{Equipment}

The equipment needed in this study include a digital scale, basin, blender, mixer, gas stove, pan, ice mold, and freezer. Other tools that were used in the analysis include colorimeter (CS-10), stopwatch (OneMed), hand refractometer (ATAGO), stainless steel holes (size 14, pore size $1.41 \mathrm{~mm}$ ).

\section{Study Design}

This study uses a Randomized Block Design (RBD) with two factors. Factor I is the type of polysaccharide (CMC, xanthan gum, agar, and pectin) and factor II is the percentage of polysaccharides $(0.5 \%, 1 \%)$. Each treatment is repeated 3 times to obtain 24 experimental units. Data are analyzed using analysis of variance (ANOVA) with a real level ( $\alpha$ ) of $5 \%$. If the results of the analysis had a significant effect, then we proceeded with the Tukey test with a real level $(\alpha)=5 \%$. Data analysis was carried out using Minitab 16 and Microsoft Excel 2013. The selection of best treatment was performed using Zeleny (1982) method.

\section{Stages of Research Making Cucumber Sorbet}

The cucumber is peeled and washed under running water, its rind and seeds are removed. The cucumber is cut into smaller sizes and mixed with other ingredients such as sugar (sugar: cucumber $=1$ : 25), lime juice, and polysaccharides (CMC/xanthan gum/agar/pectin). All ingredients are mashed in a high-speed blender for 3 minutes. Then, the sorbet dough is cooked at $70{ }^{\circ} \mathrm{C}$ for 5 minutes. After that, the dough is cooled to room temperature. The cooled dough is put in the freezer at $-18^{\circ} \mathrm{C}$ for 2 hours. Then the sorbet dough is stirred using a medium speed mixer for 3 minutes. Then, the sorbet dough is frozen in the freezer at $-18^{\circ} \mathrm{C}$ for 24 hours.

\section{Analysis Procedure}

\section{Color Test}

Color Test was performed using Yuwono (2001) method. The sample is placed in clear plastic and the color reader lens is brought closer to the sample. Then, the button for sample color measurement is pressed $\left(L_{+}=\right.$lighter; $L_{-}^{-}=$dark; $a+=$ red; $a-=$ green; $b+=$ yellow; b- = blue).

\section{Melting Speed Test}

Melting speed test was performed using Pintor, Escalona-Buendía, and Totosaus, (2017) method. The sorbet sample is placed on the stainless-steel hole at room temperature (25 $\pm 2{ }^{\circ} \mathrm{C}$ ). The weight of the sample that passes into the stainless-steel hole every 5 minutes is recorded. The measurement is carried out for 1 hour so that the melting speed can be determined ( $\mathrm{g} /$ minutes). 


\section{Total Dissolved Solid Test}

Total dissolved solid test was performed using Claudia, Rusmarilin, and Limbong (2016) method. The sorbet sample is placed on the prism, and then the prism is covered. Measurements are made by reading the scale listed.

\section{Overrun Test}

Overrun test was performed using Homayouni et al. (2008) method.

$$
\text { Overrun }(\%)=\frac{\text { weight of dough-weight of ice cream at the same volume as the dough }}{\text { weight of ice cream at the same volume as the dough }} \times 100
$$

\section{Viscosity Test}

Viscosity test was performed using Janiszewska (2014) method with modifications. The sample is tested for its viscosity value using a digital rotary viscometer. The viscosity test is carried out at room temperature. The volume of the sample tested is $150 \mathrm{ml}$.

\section{RESULT AND DISCUSSION}

The study result shows that cucumber sorbet is light green in color. The sorbet resembles an ice cream product but without the addition of milk or cream. Cucumber sorbet has a slightly sweet taste. The addition of lime in the sorbet makes the sorbet taste a little sour and more refreshing. The study result cucumber sorbet product can be seen in Figure 1.

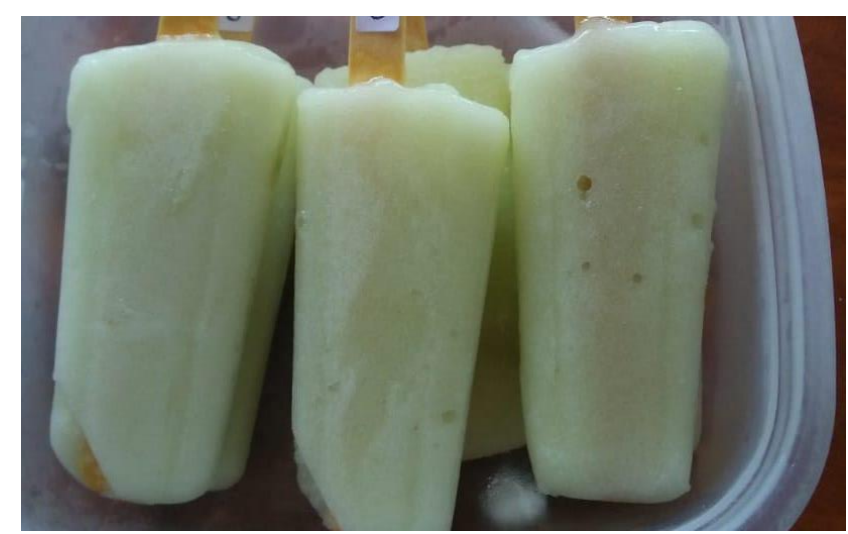

Figure 1. Cucumber Sorbet

\section{Color Test}

The color test is carried out on cucumber pulp and cucumber sorbet. The color test result on the cucumber pulp can be seen in Table 1. The color test result on the cucumber sorbet will be discussed below.

Table 1. Brightness (L), Greenness (a-), and Yellowness (b+) Values of Cucumber Pulp

\begin{tabular}{cccc}
\hline \multirow{2}{*}{ Name } & \multicolumn{4}{c}{ Color } \\
\cline { 2 - 4 } & $\mathbf{L}$ & $\mathbf{A}$ & $\mathbf{b}$ \\
\hline Cucumber Pulp & 58.06 & -8.78 & 10.03 \\
\hline
\end{tabular}

Based on the type of polysaccharide treatment and the percentage of polysaccharides, the interaction between the two treatments has a significant effect on the brightness $(\mathrm{L})$ and yellowness $(b+)$ values of sorbet $(p<0.05)$ (Table 2$)$. The treatment of $1 \%$ xanthan gum has higher brightness and yellowness values, i.e. $57.66 \pm 1.74$ and $13.57 \pm 0.66$. On the other hand, the treatment of $0.5 \%$ agar has lower brightness value (46.42). The appearance of xanthan gum and agar when both are dissolved becomes opaque (Wüstenberg, 2014). The 
use of high xanthan gum (1\%) causes the sorbet to have higher brightness and yellowness values. On the other hand, the use of low agar $(0.5 \%)$ causes the resulting sorbet to have a low brightness value.

Table 2. Mean Brightness $(\mathrm{L})$ and Yellowness $(b+)$ Values of Sorbet Due to the Treatment of Polysaccharide Types and Polysaccharide Percentages

\begin{tabular}{lccc}
\hline $\begin{array}{c}\text { Polysaccharide } \\
\text { Types }\end{array}$ & $\begin{array}{c}\text { Polysaccharide } \\
\text { Percentages }\end{array}$ & $\begin{array}{c}\text { Brightness Value } \\
(\mathbf{L})\end{array}$ & $\begin{array}{c}\text { Yellowness Value } \\
(\mathbf{b +})\end{array}$ \\
\hline CMC & & $54.09 \pm 1.37 \mathrm{ab}$ & $8.29 \pm 0.96 \mathrm{bc}$ \\
Xanthan Gum & & $54.41 \pm 1.94 \mathrm{ab}$ & $7.77 \pm 0.94 \mathrm{c}$ \\
Pectin & $0.5 \%$ & $53.70 \pm 0.98 \mathrm{ab}$ & $9.39 \pm 1.05 \mathrm{bc}$ \\
Agar & & $46.42 \pm 2.97 \mathrm{c}$ & $8.96 \pm 1.01 \mathrm{bc}$ \\
& & & \\
CMC & & $50.71 \pm 1.70 \mathrm{bc}$ & $7.77 \pm 0.94 \mathrm{c}$ \\
Xanthan Gum & $1 \%$ & $57.66 \pm 1.74 \mathrm{a}$ & $13.57 \pm 0.66 \mathrm{a}$ \\
Pectin & & $55.45 \pm 3.29 \mathrm{ab}$ & $9.92 \pm 0.47 \mathrm{bc}$ \\
Agar & & $52.94 \pm 2.45 \mathrm{ab}$ & $7.86 \pm 1.13 \mathrm{c}$ \\
\hline
\end{tabular}

The values in the column followed by different letters indicate significant differences $(p<0.05)$

Based on the treatment of polysaccharide types, there is no significant difference in the polysaccharide types of pectin, CMC, and agar against the greenness value of the sorbet. However, these three treatments are significantly different from the treatment of xanthan gum (Table 3). This could be related to the similarity in colors of pectin, CMC, and agar when dissolved in water. Pectin and agar, when dissolved in water, make the color of the solution opaque, while CMC, when dissolved in water, makes the color of the solution clear (Wüstenberg, 2014). This causes the color of the cucumber sorbet dough to remain unchanged even after being added by pectin, CMC, and agar polysaccharides. The treatment of xanthan gum is significantly different from the treatments of pectin and CMC and has the lowest greenness value $(-6.01 \pm 0.41)$. This is because xanthan gum has low gel transparency (Wüstenberg, 2014).

The mean greenness value of the polysaccharide percentage is $0.5 \%$ higher $(-6.71 \pm$ 0.38 ) than the $1 \%$ polysaccharide percentage $(-6.27 \pm 0.49)$ (Table 3$)$. This can be because the color of the treatment of $0.5 \%$ polysaccharide percentage is closer to the color of the cucumber pulp $(\mathrm{a}=-8.78)$. After all, the amount of polysaccharide added to the sorbet making is less than the treatment of $1 \%$ polysaccharide percentage.

Table 3. Mean Greenness Value (a-) of Sorbet Due To the Treatment of Polysaccharide Types and Polysaccharide Percentages

\begin{tabular}{cc}
\hline Polysaccharide Types & Mean Greenness Value (a-) \\
CMC & $-6.73 \pm 0.21 \mathrm{~b}$ \\
Xanthan Gum & $-6.01 \pm 0.41 \mathrm{a}$ \\
Pectin & $-6.74 \pm 0.23 \mathrm{~b}$ \\
Agar & $-6.50 \pm 0.63 \mathrm{ab}$ \\
\hline Polysaccharide Percentages & Mean Greenness Value $(\mathrm{a}-)$ \\
\hline $.5 \%$ & $-6.71 \pm 0.38 \mathrm{~b}$ \\
\hline$\%$ & $-6.27 \pm 0.49 \mathrm{a}$ \\
\hline The values in the column followed by different letters indicate significant differences $(\mathrm{p}<0.05)$
\end{tabular}

\section{Melting Speed, Total Dissolved Solid (TDS), and Overrun Tests}

The mean values of melting speed, TDS, and overrun can be seen in Table 4. Based on the result of the variance analysis, it can be seen that the treatments of polysaccharide types and polysaccharide percentages have no significant effect on melting speed, TDS, and overrun of the sorbet $(p<0.05)$. 
The melting speed of the cucumber sorbet ranges between $2.81-5.59 \mathrm{~g} /$ minutes. The lowest melting speed is found in the treatment of CMC $1 \%(2.71 \mathrm{~g} /$ minutes $)$. One of the factors that influence the melting speed is the use of the stabilizer and also its amount. The stabilizer serves to increase the thickness of the dough and can increase the ability to absorb water so that the product does not melt easily (Claudia et al., 2016). CMC is a hydrocolloid which can increase viscosity (Wüstenberg, 2014). The use of CMC at high concentrations can increase the solid content in the sorbet dough so that the dough will become thicker. This causes a decrease in the freezing point during the freezing process so that the structure of the sorbet product becomes denser and causes the product to melt more slowly (Ida et al., 2018).

The TDS value of cucumber sorbet ranges between $6.57-8.00{ }^{\circ}$ Brix. The type of polysaccharide and the percentage of polysaccharides do not significantly affect the TDS value of cucumber sorbet $(p<0.05)$. Dissolved solids contained in a food product consist of water-soluble components, such as fructose, glucose, sucrose, and water-soluble protein. The increase in the TDS value is also associated with a decrease in water content (Sapriyanti, Nurhartadi, and Ishartani, 2014).

Overrun is the expansion force found in products that are subjected to agitation (stirring) and freezing during the manufacturing process, such as ice cream and sorbet. Good sorbet overrun value is between $25 \%-45 \%$ (Arbuckle, 1986), while the overrun value of the cucumber sorbet only ranges between $0.20-0.48 \%$. This can be due to the thickness of the sorbet dough. Based on observations, the viscosity value of the sorbet dough for all treatments is $99.90 \mathrm{mPa}$.s. If the thickness of the dough increases, the overrun value will decrease further. Also, the thicker the dough, the higher the surface tension of the dough. The thick feature of the dough makes it difficult for air to penetrate the surface of the dough, so that the product is more difficult to swell (Arbuckle, 1986).

\section{The Best Treatment}

Based on the calculation results using Zeleny (1982) method, the best treatment is found in the treatment of $1 \%$ xanthan gum. The best treatment has a brightness value $(\mathrm{L})$ of 57.66 ; greenness value $(a-)$ of -5.79 ; yellowness value $(b+)$ of 13.57 ; melting speed of $2.81 \mathrm{~g} /$ minutes; total dissolved solid of $7.60^{\circ}$ Brix; and overrun of $0.32 \%$.

Table 4. Effect of polysaccharide types and polysaccharide percentages on the mean values of total dissolved solids of cucumber sorbet

\begin{tabular}{ccccc}
\hline $\begin{array}{c}\text { Polysaccharide } \\
\text { Types }\end{array}$ & $\begin{array}{c}\text { Polysaccharide } \\
\text { Percentages } \\
(\%)\end{array}$ & $\begin{array}{c}\text { Melting } \\
\text { Speed } \\
\text { (g/minutes) }\end{array}$ & $\begin{array}{c}\text { Total } \\
\text { Dissolved } \\
\text { Solids (TDS) } \\
\text { ('Brix) }\end{array}$ & $\begin{array}{c}\text { Overrun } \\
\text { (\%) }\end{array}$ \\
\hline CMC & 0.5 & $4.64 \pm 1.77$ & $7.50 \pm 0.44$ & $0.47 \pm 0.13$ \\
& 1 & $2.71 \pm 1.03$ & $7.40 \pm 0.26$ & $0.38 \pm 0.14$ \\
Xanthan Gum & 0.5 & $2.95 \pm 0.28$ & $7.17 \pm 0.29$ & $0.48 \pm 0.02$ \\
& 1 & $2.81 \pm 0.11$ & $6.67 \pm 1.53$ & $0.32 \pm 0.03$ \\
Pectin & 0.5 & $4.81 \pm 1.04$ & $8.00 \pm 0.50$ & $0.36 \pm 0.29$ \\
& 1 & $5.59 \pm 2.01$ & $7.60 \pm 0.53$ & $0.40 \pm 0.28$ \\
Agar & 0.5 & $4.51 \pm 1.78$ & $7.77 \pm 0.40$ & $0.27 \pm 0.13$ \\
& 1 & $4.40 \pm 0.93$ & $6.57 \pm 0.81$ & $0.20 \pm 0.04$ \\
\hline
\end{tabular}

\section{CONCLUSION}

Based on the study results, the interaction between the polysaccharide types and the polysaccharide percentages has a significant effect on the brightness $(L)$ and yellowness $(b$ + ) values of the sorbet, and has no significant effect on the values of melting speed, TDS, and overrun of the sorbet $(p<0.05)$. The treatment of polysaccharide types and the polysaccharide percentages significantly affects the greenness value (a-) of the sorbet. The best treatment for 
cucumber sorbet is cucumber sorbet which uses $1 \%$ xanthan gum in its manufacture. Cucumber sorbet with a low sugar composition and involving the use of polysaccharides in its manufacture can be a type of frozen snack that is beneficial to the human body. Cucumber sorbet has a very low overrun value of $0.20-0.48 \%$, which means that the development of cucumber sorbet is still very low.

\section{REFERENCES}

Arbuckle, W. S. (1986). Ice Cream. https://doi.org/10.1007/978-1-4615-7222-0

Cahyadi, W., \& Widiantara, T. (2018). Penambahan Konsentrasi Bahan Penstabil dan Sukrosa terhadap Karakteristik Sorbet Murbei Hitam. Pasundan Food Technology Journal, 4(3), 218-224. https://doi.org/10.23969/pftj.v4i3.649

Claudia, N. B., Rusmarilin, H., \& Limbong, L. N. (2016). Pengaruh Perbandingan Sari Labu Kuning dengan Sari Nenas dan Penambahan Gelatin terhadap Mutu Sorbet Air Kelapa. J.Rekayasa Pangan Dan Pert., 4(4), 500-507.

Hendrianto, E., \& Rukmi, W. D. (2015). Pengaruh Penambahan Beras Kencur pada Es Krim Sari Tempe terhadap Kualitas Fisik dan Kimia. Jurnal Pangan Dan Agroindustri, 3(2), 353-361.

Hipólito, C., Ramalheira, R., Beirão da Costa, S., \& Moldão-Martins, M. (2015). The Effect of Fruit Cultivar/Origin and Storage Time on Sorbets Quality. LWT - Food Science and Technology, 68, 462-469. https://doi.org/10.1016/j.Iwt.2015.12.054

Homayouni, A., Azizi, A., Ehsani, M. R., Yarmand, M. S., \& Razavi, S. H. (2008). Effect of Microencapsulation and Resistant Starch on The Probiotic Survival and Sensory Properties of Synbiotic Ice Cream. Food Chemistry, 111(1), 50-55. https://doi.org/10.1016/j.foodchem.2008.03.036

Ida, S., Ari Sandhi W, P., \& Kartika Pratiwi, I. D. P. (2018). Pengaruh Konsentrasi Jus Daun Pegagan dan Perbandingan CMC dengan Maizena terhadap Karakteristik Sorbet. Jurnal IImu Dan Teknologi Pangan (ITEPA), 7(1), 33-42. https://doi.org/10.24843/itepa.2018.v07.i01.p04

Janiszewska, E. (2014). Microencapsulated Beetroot Juice as A Potential Source of Betalain. Powder Technology, 264, 190-196. https://doi.org/10.1016/j.powtec.2014.05.032

Pintor, A., Escalona-Buendía, H. B., \& Totosaus, A. (2017). Effect of Inulin on Melting and Textural Properties of Low-fat and Sugar-reduced Ice Cream: Optimization Via a Response Surface Methodology. International Food Research Journal, 24(4), 17281734.

Salehi, B., Martorell, M., Arbiser, J., Sureda, A., Martins, N., Maurya, P., ... Sharifi-Rad, J. (2018). Antioxidants: Positive or Negative Actors? Biomolecules, 8(4), 124. https://doi.org/10.3390/biom8040124

Sapriyanti, R., Nurhartadi, E., \& Ishartani, D. (2014). Karakteristik Fisikokimia dan Sensori Velva Tomat (Lycopersicum esculentum Mill) dengan Pemanis Madu. Jurnal Teknologi Hasil Pertanian, 7(1), 59-69. https://doi.org/10.20961/jthp.v0i0.12920

Yuwono, S. S. (2001). Pengujian Fisik Pangan. Surabaya: Surabaya Unesa University Press.

Uzuazokaro, M.-M. A., Okwesili, F. C. N., \& Chioma, A. A. (2018). Phytochemical and Proximate Composition of Cucumber (Cucumis sativus) Fruit from Nsukka, Nigeria. African Journal of Biotechnology, 17(38), 1215-1219. https://doi.org/10.5897/AJB2018.16410

Wüstenberg, T. (2014). Cellulose and Cellulose Derivatives in the Food Industry. https://doi.org/10.1002/9783527682935.index

Zeleny, M. (1982). Multiple Criteria Decision Making (McGraw-Hill Series in Quantitative Methods for Management). New York: McGraw-Hill. 